\title{
Lynch syndrome (HNPCC)
}

\author{
Józef Kładny', Jan Lubiński \\ 'Department of General and Oncological Surgery, Pomeranian Medical University, Szzzecin, Poland \\ 2International Hereditary Cancer Centre, Department of Genetics and Pathology, Szczecin, Poland
}

Corresponding author: Józef Kładny, Department of General and Oncological Surgery, Pomeranian Medical University, 72 Powstańców Wielkopolskich Str., 70-111 Szczecin, Poland, phone: +48914661160,e-mail: jkladny@sci.pam.szczecin.pl

It is estimated that a highly penetrant genetic predisposition is the cause of $10-20 \%$ of all colorectal cancers (CRC) [1-5].

Among the well known syndromes of inherited predisposition to tumours manifesting with CRC, syndromes showing a Mendelian pattern of inheritance include: hereditary nonpolyposis colorectal cancer (HNPCC, Lynch syndrome), familial adenomatous polyposis (FAP), Gardner, Turcot and Peutz-Jeghers syndromes, and juvenile polyposis.

\section{Lynch syndrome (HNPCC)}

HNPCC was described by Lynch [6] in the 1960 s and is the cause of around $5 \%$ of all CRC. It has been shown that HNPCC is caused by mutations within several genes such as: MSH2, MLH1, MSH6, PMS2. Mutation within $\mathrm{MSH} 2$ and $\mathrm{MLH} 1$ are the most frequent cause of Lynch syndrome [7-10]. Characteristic clinical features of Lynch syndrome include:

- early age of CRC diagnosis (about 45 years),

- more frequent right side tumour localization,

- two or more CRC cases among first degree relatives,

- many syn- and meta-chronous CRC tumours,

Table 1. Diagnostic criteria of HNPCC according to ICG-HNPCC [1 1]

1. At least 3 relatives are affected by histologically verified CRC or cancer of the endometrium, small bowel or urinary tract; at least one of them is a first degree relative of the other two; FAP is excluded*

2. At least 2 of the above persons are first degree relatives from two different generations

3. At least 1 of the above persons has cancer diagnosed at age under 50 years

All other parameters (right side localization, syn- or metachronous tumours) should be treated as non-diagnostic features.

${ }^{*}$ Colorectal polyposis, congenital hypertrophy of the retinal pigment epithelium, cysts and osteomas of the mandible/maxilla and desmoids are excluded
- occurrence of disease in consecutive generations (vertical transmission),

- increased frequency of occurrence among relatives of cancers of the endometrium, small bowel and urinary tract.

According to an international group of experts (the International Collaborative Group on HNPCC - ICGHNPCC) Lynch syndrome can be definitively diagnosed if constitutional mutations within one of the genes connected with HNPCC, such as MSH2 or MLH1, is identified or if the following pedigree-clinical criteria are matched (Table 1).

A family matching the definitive criteria of HNPCC according to the ICG-HNPCC are presented in Figure 1.

Due to incomplete penetrance of genes, which is typical for dominant Mendelian disorders, deaths caused by various diseases, or due to difficulties in achieving full information about all relatives, a large proportion - perhaps the majority - of families with HNPCC cannot be diagnosed using the Amsterdam criteria summarized in Table 1.

Therefore several authors use another type of criteria, fulfilment of which does not allow definitive diagnosis of HNPCC, but is useful in identifying of families with

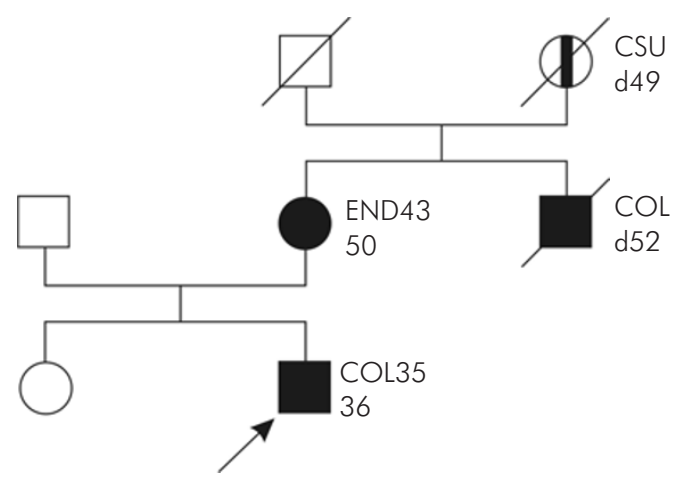

Figure 1. Family pedigree matching HNPCC criteria, according to ICG-HNPCC 
Table 2. Diagnostic criteria of "suspected HNPCC" [16]

1. Among first degree relatives of a CRC patient (or in himself) at least one CRC, cancer of the endometrium, small bowel or urinary tract

2. At least one of the above cancers diagnosed under age 50

3. FAP is excluded*

*See Table 1

a highly increased risk of disease [12-15]. According to our experience the criteria summarized in Table 2 are of particular value in identifying cases suspected of HNPCC.

Examples of families matching the criteria of "suspected HNPCC" are presented in Figures 2-3.

\section{Molecular diagnostics of constitutional mutations in genes associated with HNPCC}

Such diagnostics was described in the section "MSH2/MLH1 testing". Detection of marker mutation for a family with HNPCC is of clinical importance because it:

a) allows exclusion of around 50\% of relatives from the high risk group, and

b) facilitates surgical decision making, for example instead of a classical tumour resection colectomy with prophylactic hysterectomy and ovariectomy when such resections are performed in female mutation carriers at perimenopausal age.

\section{Management of families with HNPCC}

Our present knowledge about this syndrome indicates that special prevention and treatment should be applied. Different programmes are performed by particular centres $[4,16,17]$. According to the latest data, relatives from families with Lynch syndrome

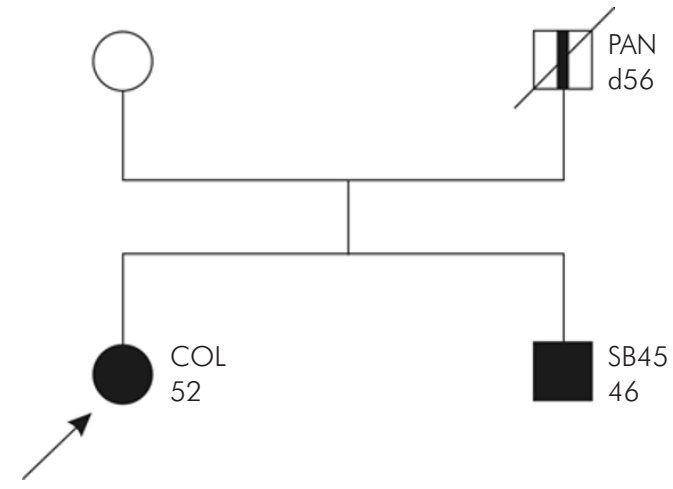

Figure 2. Family pedigree "suspected HNPCC" should consider the following options of medical management.

\section{Diet optimization}

Persons with high risk of CRC should consider a low fat diet with limitations concerning red meat, but with bran and rich in cellulose [18].

\section{Pharmacological prevention}

There are reports that the group of drugs lowering the risk of CRC includes: aspirin, sulindac, prioxicam, calcium, and vitamin C. The real value of such drugs in cancer prevention in HNPCC cannot be excluded, but is not proven $[17,19,20]$.

\section{Colonoscopy}

Full colonoscopy is recommended from the ages of 20-25 years every one - two years. In families in which CRC has been diagnosed at earlier ages colonoscopy should begin 5 years earlier than the age of the youngest person with CRC. In cases where endoscopy the colon could not be assessed properly, a barium enema is indicated [17, 21].

\section{Extra-colonic tumour diagnostics}

Due to the increased frequency of female genital tract tumours in women with HNPCC, it is recommended to perform, beginning at the age of 35 years, annual clinical gynaecological examinations with transvaginal ultrasonography (USG) and histopathological examination of the endometrium. Additionally, in some cases it is indicated to perform an examination aimed at detecting other tumours more frequently observed in a given family (for example stomach, urinary tract and breast) $[5,17]$.

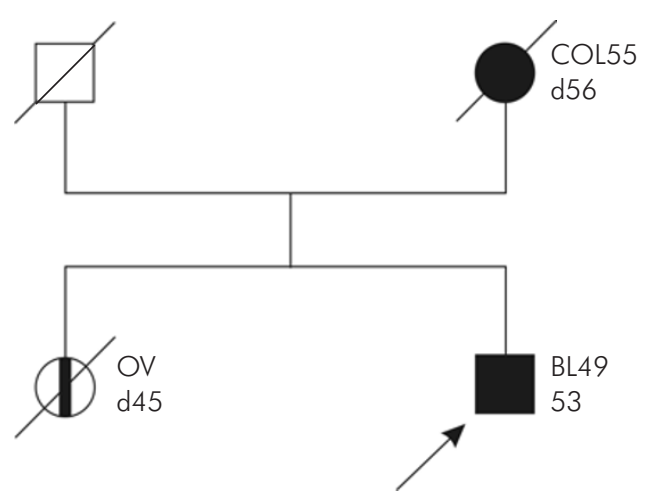

Figure 3. Family pedigree "suspected HNPCC" 


\section{Surgery}

Endoscopic polypectomy is recommended in the case of polyps which are benign and non-recurrent. However, in patients with adenomas that are multiple and/or recurrent and/or of a significant degree of dysplasia and/or villous, prophylactic colectomy should be considered [21]. Most experts believe that prophylactic surgery should not be recommended to patients without any pathological changes of the colon even if such persons are carriers of a mutation [17]. The high proportion of synchronous tumours (more than 15\% of patients at the time of diagnosis) or metachronous tumours (about $45 \%$ during 10 years following surgery of the primary tumour) suggests that for preventive surgery as for surgery in patients from HNPCC families with histopathologically diagnosed CRC the following types of surgical treatment can be recommended $[17,21]$ :

- proctocolectomy with ileostomy,

- colectomy with ileo-rectal anastomosis,

- proctocolectomy with ileo-anal "pouch" - S, J, W or H.

The first of the proposed procedures is the most radical but later the risk of recurrence is very low. However, such treatment is highly traumatising and frequently leads to urinary tract abnormalities and sexual dysfunction.

Colectomy with ileorectal anastomosis does not lead to such complications but should be followed by frequent examinations due to the risk of cancer in the unresected fragment of bowel.

Proctocoloctomy with ileo-anal "pouch" S, J, W or $\mathrm{H}$ is a method with a relatively short history so it is difficult to conclude about it definitely.

In females with Lynch syndrome undergoing surgery due to CRC and at perimenopausal age or older, due to increased risk of primary endometrial and ovarian cancers, it is recommended to consider extension of the surgery by hysterectomy and adnexectomy $[17,22]$.

All of the above procedures are characterized by increasing frequency of complications. However, they are recommended in the treatment of HNPCC because the really important problem for this patient is the high risk of second primary CRC.

It has been shown that the application of appropriate programmes of management in families with HNPCC leads to increased detection of early asymptomatic CRC. Additionally, prospective studies have confirmed that due to appropriate management the lifetime risk of CRC decreases, from 80 to $30 \%$, and there is a higher proportion of healing and longer survival time of patients with CRC from families with Lynch syndrome. Correct management applied in carriers of $M S H 2 / M L H 1$ mutations means that such persons cannot die due to CRC [23].

\section{References}

1. Lovett $\mathrm{E}$. Family studies in cancer of the colon and rectum. $\mathrm{Br}$ J Surg 1976; 63: 13-18.

2. Lynch HT, Lynch J, Lynch P. Management and control of familial cancer. In: Mulvill JJ, Miller RW, Fraumeni JF (eds.). Genetics of Human Cancer. New York, Raven Press, 1977; 3: 235-255.

3. Ponz de Leon M, Sassatelli R, Sacchetti C, Zanghieri G, Scalmati A, Roncucci L. Familial aggregation of tumors in the three-year experience of a population-based colorectal cancer registry. Cancer Res 1989; 49: 4344-4348.

4. Lynch HT, Smyrk T, Watson P, Lanspa St, Boman B, Lynch P, Lynch J, Cavalieri J. Hereditary colorectal cancer. Seminars in Oncology 1991 ; 18: 337-366.

5. Vasen $\mathrm{H}$. Inherited forms of colorectal, breast, and ovarian cancer. Surg Oncol Clin N Am 1994; 3: 501

6. Lynch HT, Krush AJ. Cancer family "G" revisited: 1895-1970. Cancer 1971; 27: 1505-1511.

7. Fishel R, Lescoe MK, Rao MR, Copeland NG, Jenkins NA, Garber J, Kane M, Kolodner R. The human mutator gene homolog MSH2 and its association with hereditary nonpolyposis colon cancer. Cell 1993; 75: 1027-1038.

8. Leach FS, Nicolaides NC, Papadopoulos N, Liu B, Jen J, Parsons R, Peltomaki P, Sistonen P, Aaltonen LA, Nystrom-Lahti M, Guan XY, Zhang J, Meltzer PS, YU J-W, Kao F-T, Chen DJ, Cerosaletti KM, Fournier REK, Todd S, Lewis T, Leach RJ, Naylor SL, Weissenbach J, Mecklin JP, Järvinen H, Peterson GM, Hamilton SR, Green J, Jass J, Watson P, Lynch HT, Trent JM, De la Chapelle A, Kinzler KW, Vogelstein B. Mutations of a mutS homolog in hereditary nonpolyposis colorectal cancer. Cell 1993; 75: 1215-1225.

9. Nicolaides NC, Papadopoulos N, Liu B, Wei Y-F, Carter KC, Ruben SM, Rosen CA, Haseltine WA, Fleischmann RD, Fraser CM, Adams MD, Venter JC, Dunlop MG, Hamilton SR, Petersen GM, De la Chapelle A, Vogelstein B, Kinzler KW. Mutations of two PMS homologues in hereditary nonpolyposis colon cancer. Nature 1994; 371: 75-80.

10. Papadopoulos N, Nicolaides NC, Wei Y-F, Ruben SM, Carter KC, Rosen CA, Haseltine WA, Fleischmann RD, Fraser CM, Adams MD, Venter JC, Hamilton SR, Petersen GM, Watson P, Lynch HT, Peltomaki P, Mecklin JP, De la Chapelle A, Kinzler KW, Vogelstein B. Mutation of a mutl homolog in hereditary colon cancer. Science 1994; 263: 1625-1629.

11. Vasen HF, Mecklin JP, Khan PM, Lynch HT. The International Collaborative Group on Hereditary Non-Polyposis Colorectal Cancer (ICG-HNPCC). Dis Colon Rectum 1991; 34: 424-425.

12. Vasen HF, Watson P, Mecklin JP, Lynch H, and the ICG-HNPCC. New clinical criteria for hereditary nonpolyposis colorectal cancer (HNPCC, Lynch syndrome) proposed by the International Collaborative Group on HNPCC. Gastroenterology 1999; 116 : 1453-1456.

13. Rodriguez-Bigas MA, Boland CR, Hamilton SR, Henson DE, Jass JR, Khan PM, Lynch H, Perucho M, Smyrk T, Sobin L, Srivastava S. A National Cancer Institute Workshop on Hereditary Non-polyposis Colorectal Cancer Syndrome: meeteng highlights and Bethesda Guidelines. J Natl Cancer Inst 1997; 89: 17581762

14. Park JG, Vasen HF, Park KJ, Peltomaki P, et al. Suspected hereditary nonpolyposis colorectal cancer. Dis Colon Rectum 1999; 42: 710-716.

15. Park JG, Vasen HF, Park YJ, Park KJ, Peltomaki P, de Leon MP, Rodriguez-Bigas MA, Lubinski J, Beck NE, Bisgaard ML, Miyaki M, Wijnen JT, Baba S, Lindblom A, Madlensky L, Lynch HT. Suspected HNPCC and Amsterdam criteria II: evaluation of 
mutation detection rate, an international collaborative study. Int J Colorectal Dis 2002; 17: 109-114.

16. Vasen HF, Mecklin JP, Watson P, Utsunomiya J, Bertario L, Lynch $P$, Svendsen LB, Cristofaro G, Müller HJ, Khan PM, Lynch HT. Surveillance in Hereditary Nonpolyposis Colorectal Cancer: an international cooperative study of 165 families. The International Collaborative Group on HNPCC. Dis Colon Rectum 1993; 36: $1-4$

17. Lynch HT, Lynch J. Lynch syndrome: natural history, genetic counseling and prevention. J Clin Oncol 2000; 18 (21 Suppl): 19S-31S.

18. Willet WC, Stampfer MJ, Colditz GA, Rosner BA, Speizer FE. Relation of meat, fat, and fiber intake to the risk of colon cancer in a prospective study among women. N Engl J Med 1990; 323: 1664-1672.

19. Bralow SP. Primary and secondary chemoprevention of colorectal cancer: Hereditary colorectal cancer. Springer Verlag Tokyo $1990 ; 231$.

20. Muscat JE, Stellman SD, Wynder EL. Nonsteroidal antiinflammatory drugs and colorectal cancer. Cancer 1994; 74: 1847 . 1854.

21. Vasen HF, Nagengast FM, Khan PM. Interval cancers in hereditary non-polyposis colorectal cancer (Lynch syndrome). Lancet 1995; 345: 1183-1184

22. Watson P, Vasen HF, Mecklin JP, Järvinen H, Lynch HT. The risk of endometrial cancer in hereditary nonpolyposis colorectal cancer. Am J Med 1994; 96: 516-520.

23. Järvinen HJ, Aarnio M, Mustonen H, Aktan-Collan K, Aaltonen LA, Peltomäki P, De La Chapelle A, Mecklin JP. Controlled 15-year trial on screening for colorectal cancer in families with hereditary nonpolyposis colorectal cancer. Gastroenterology 2000; 118 : 829-834. 